\begin{tabular}{|l|l|}
\hline & \\
\hline &
\end{tabular}

SEÇÃO: ESTÉTICA

\title{
Arte cristã, paradoxo e Pós-modernidade
}

\author{
Christian art, paradox and Postmodernism \\ Arte cristiano, paradojo y posmodernidad
}

\section{Ronel Alberti da Rosa ${ }^{1}$ \\ orcid.org/0000-0001-7777-2779 \\ albertidarosa@yahoo.com.br}

Recebido em: 04 set. 2020

Aprovado em: 02 mar. 2021. Publicado em: 24 jun. 2021.
Resumo: A história da arte no Ocidente é a história da arte cristã. Imagens, motivos, símbolos, técnicas, personagens: o Cristianismo deu a marca distintiva da arte europeia e ocidental por dois mil anos; o Cristianismo balizou a arte do Ocidente. As raizes mais profundas da arte cristã, contudo, não estão expostas: sua natureza e suas mais legitimas pulsões são ignoradas, mesmo pelo público confessional. O resultado inevitável é a eclosão periódica de polêmicas e mal-entendidos. O objetivo deste artigo é demostrar que a arte cristã nunca foi avessa a paradoxos estéticos, e que os elementos transculturais da criação pós-moderna foram gestados em um longo processo técnico e estético-filosófico precipuamente cristão. Palavras-chave: Arte. Cristianismo. Feiúra. Pós-modernidade.

Abstract: The history of Western art is the history of Christian art. Christianity has provided the distinguishing marks of European and Western art for two millennia: images, motifs, symbols, technics and personages. However, the deepest roots of Christian art aren't exposed; its very nature and its most legitimate drives are ignored, even by the confessional public. The unavoidable outcome from that is the periodical outburst of polemics and misunderstandings. This paper aims to demonstrate that Christian art has never been refractory to aesthetical paradoxes and that, besides, the transcultural elements and technics of postmodern art have been borne along a process that was aesthetically and philosophically mostly a Christian one.

Keywords: Art. Christianity. Ugliness. Postmodernism.

Resumen: La historia del arte en el Occidente es la historia del arte cristiano. Imágenes, motivos, símbolos, técnicas, personajes: el Cristianismo ha puesto su señal en el arte europeo y occidental por dos mil años; el Cristianismo ha trazado las fronteras del arte occidental. Las raices más hondas del arte cristiano, empero, no se encuentran expuestas: su naturaleza y sus más legítimas pulsiones son ignoradas por el público confesional mismo. El resultado inevitable es la periódica explosión de polémicas y mal-entendidos. El objeto de este artículo es demonstrar que el arte cristiano no ha sido nunca contrario a paradojos estéticos, y que los elementos transculturales de la creación posmoderna han sido gestados en un largo desarrollo técnico y estético-filosófico fundamentalmente cristiano. Palabras clave: arte, Cristianismo, fealdad, Posmodernidad.

\section{Introdução}

A arte cristã, apesar de quase onipresente na sociedade ocidental, permanece-lhe tão estranha quanto qualquer objeto de arte contemporânea. Dentre as consequências negativas desse desconhecimento, relembre-se o encerramento prematuro da exposição "Queermuseu cartografias da diferença na arte brasileira", no Santander Cultural, em Porto Alegre, em outubro de 2017. Recordar o processo de gestação do objeto artístico, que dialogue com o Evangelho cristão, pode ajudar a
Artigo está licenciado sob forma de uma licença Creative Commons Atribuição 4.0 Internacional. 
que se reconheçam as razões mais legítimas de um diálogo que fundou o conceito de Ocidente em posição ao de Oriente. Demonstraremos que a arte cristã não admite o princípio do exclusivismo, ao contrário, ademais de ser caudatária de uma metafísica neoplatônica, resulta, paradoxalmente, da confluência daquela com um pronunciado impulso assimilatório, o que é responsável por tê-la tornado capaz de afirmar-se, por séculos, como a corrente estética mais experimental e, mesmo, revolucionária da cultura ocidental. Os processos de assimilação se desenvolveram com vigor e velocidades diferentes nos vários territórios cristãos de Europa e norte da África, mas mantiveram sempre uma abertura para as culturas nativas e para as diferentes cosmogonias pagãs que, até o século IX, ainda eram muito vivas no imaginário dos povos europeus. ${ }^{2}$

Para tanto, este artigo trabalhará com os eixos histórico - em que será demonstrado o tipo de relação da arte cristã para com seu entorno político e social - , técnico - em vista de o processo de emancipação da obra de arte ter sido impulsionado pelo refinamento, em grande parte, de conceitos técnicos, que foram inaugurados pelo Evangelho de João - e estético-filosófico-teológico - que embasa a filosofia da religião cristã desde seus primórdios.

\section{As contradições das imagens}

Este artigo surgiu da necessidade de retomar alguns fatos básicos acerca da arte cristã, em vista da recente polemização e, em especial, dos inqualificáveis eventos que levaram ao cancelamento da exposição "Queermuseu - cartografias da diferença na arte brasileira", em Porto Alegre, 20173. Algumas obras que retratavam imagens e objetos relacionados com a religião cristã e sua problemática recepção por uma parcela da população são apenas a mais recente expressão do abismo que se abriu entre a arte contemporânea e a desinformação de uma parte do público, que se encontra viciada em arte dócil, para consumo e descarte imediato. Esse sentimento tem raizes naquilo que Adorno (1977) identificou como sendo o papel precípuo da arte, que seria o de introduzir o caos na ordem, não o inverso. A mentalidade burguesa, que esperaria da arte uma confirmação do status conquistado por essa classe, sentir-se-ia, dessa forma, defraudada. As contradições no seio da sociedade capitalista seriam, portanto, expostas pela arte contemporânea - um discurso afrontoso a um estamento social, que dele esperaria nada além da legitimação, e que está entranhado em todas as mídias. No caso da música, como Adorno observa, são as dissonâncias da música nova que a fazem insuportável: a suspensão das categorias hierárquicas de consonância e dissonância e a superação do conceito de tonalidade são sintomas da chegada de um novo padrão de valoração, padrão esse não apenas alheio, mas oposto aos resquicios de mentalidade Ancien Régime, que subsistem no imaginário do consumidor e do colecionador de arte contemporânea.

Este trabalho não abordará as diferenças - às vezes consideráveis - entre a arte cristã ortodoxa, católica e protestante. Também não será feita diferença entre arte sacra, produzida expressamente para uso nos templos, e arte de inspiração cristã, produzida por artistas independentes.

É preciso ter clareza de que a disputa que se está travando hoje, da mesma forma que a querela da iconoclastia, nos séculos VIII-IX, é por padrões de linguagem. Uma camada do público exige receber uma versão unidimensional do mundo, uma representação apenas da superfície edulcorada e maquiada de uma realidade "Matrix", que acreditam ser exclusivamente virtuosa e bela 4 . Esse desejo é compreensivel, pois a arte contemporânea, provocativa e exploradora de camadas subconscientes da mente, lhes é impenetrável.

\footnotetext{
Ver WIND, Edgar. Misteri pagani nel Rinascimento. Milano: Adephi Edizioni, 1999

3 A exposição foi encerrada prematuramente pelo Santander Cultural de Porto Alegre, em 10 de setembro de 1017, alegando o banco ter recebido "diversas críticas sobre a exposição" e que constataram que "algumas das obras desrespeitavam símbolos, crenças e pessoas, o que não está em linha com a nossa visão de mundo" (disponivel em: https://www.facebook.com/SantanderCultural/posts/732513686954201). 4 A frase de Walter Benjamin, de que "é necessário pentear a história a contrapelo" (Es ist nötig, die Geschichte gegen den Strich zu bürsten, BENJAMIN, 2002, p. 101), remete ao fato de que as relações dentro de uma sociedade estão ocultas ao grande público; a este, se apresenta apenas uma versão embelezada - a história oficial é sempre gloriosa e bela. Por baixo dela, porém, ao "pentear-se a história a contrapelo", é possivel encontrar a narrativa daqueles que não participam da oficialidade, de tudo aquilo que é queer e resiste à assimilação pela totalidade.
} 
Impenetrável ou, como escreveu Adorno, irritante, por lhes falar de suas próprias contradições 5 . Em dois mil anos de história, a sociedade ocidental produziu gerações de gigolôs da arte. Compra-se arte, paga-se por ela e, portanto, espera-se dela que cumpra o papel para o qual ela está sendo paga: eis a chave para entender o mal-estar para com a arte não bela. Contudo, tentar dar conta da complexidade do fenômeno estético cristão com ferramentas reducionistas é uma empreitada destinada ao fracasso. A arte cristã é antropofágica, sempre o foi. Ela se desenvolveu canibalizando técnicas e mestiçando-se com influências externas a ela. A errônea impressão que se difundiu sobre a arte cristã, de que seria purista, tradicionalista, avessa a inovações e esclerosada, tem sua origem no historicismo do periodo iluminista e no Romantismo. A Aesthetica, de Alexander Baumgarten [1750] (2007), delimitou muito bem o escopo da nova ciência da estética: viria como ferramenta auxiliar à tarefa de sondar e iluminar regiões ainda não tocadas pelas disciplinas da Lógica e da Metafísica. O conhecimento enciclopédico poderia, a partir de Baumgarten, se dedicar a catalogar uma taxonomia estética, que visaria enriquecer o processo gnosiológico do Esclarecimento oitocentista.

\$1 AESTHETICA (theoria liberalium artium, gnoseologia inferior, ars pulcre cogitandi, ars analogi rationis) est scientia cognitionis sensitivae. § 2 Naturalis facultatum cognoscitivarum inferiorum gradus solo usu citra disciplinalem culturam auctus AESTHETICA NATURALIS dici potest, et distingui, sicuti logica naturalis solet, in connatam, ingenium pulcrum connatum, et acquisitam, et haec denuo in docentem et utentem. (BAUMGARTEN, 2007, p. 92).

Já antes disso, a lgreja sempre fizera o máximo empenho para financiar a arte mais moderna, a mais ousada, a que se servisse dos meios técnicos mais avançados à disposição. Não se deve descartar a hipótese de que uma das causas do divórcio entre o público e a arte contemporânea resida no vazio deixado pela Igreja, ao se retirar de seu papel milenar de mecenas. Pela primeira vez, em meados de 1750, a arte sacra europeia passou a recuperar linguagens pregressas; tinha início um processo de idealização do passado e de toda arte nele produzida. Friedrich Nietzsche (1952), em O nascimento da Tragédia, defendeu a tese de que a romantização do passado termina por anestesiar o ferrão crítico, que uma vez estivera ativo sob a superfície da criação artística. Ele se referia à arte grega antiga, que Winckelmann, com suas teorias idealistas, transformara em um bibelô serenojovial, mas o mesmo se pode dizer de toda arte cristã, que uma parcela mal informada da população ainda, e especialmente hoje, só consegue enxergar por um viés piegas e simplório. Nietzsche, paradoxalmente um homem do século XIX, é um crítico do Romantismo: para ele, o historicismo romântico - que, mais tarde, com teorias derivadas de Hegel, chegaria a dominar a academia - estaria empreendendo uma aproximação da Antiguidade, que terminaria por fazer dela algo que nunca fora. A critica nietzscheana ao teatro de Euripedes encontra nisso sua justificativa: substituir o processo teatrológico original - o de Ésquilo - por uma pedagogia socrática corresponderia a recriar com preconceitos do século XIX, uma arte que, em sua origem, tivera uma função social, que os contemporâneos de Nietzsche não estavam interessados em prescrutar.

O Cristianismo nasceu num espaço político-econômico latino, isso é, a administração romana. Mas sua esfera cultural é o Helenismo e, por isso, a arte cristã é transversal, é queer e paradoxal.

[...] A palavra queer, cujo sentido original era bizarro, excêntrico, estranho, passou a designar depreciativamente os homossexuais a partir do século XIX. Nos anos 1980, porém, a palavra foi reivindicada pelos grupos LGBT num processo de ressignificação em que se tornou valorativa. Com essa transformação de sentido, o termo começou a ser usado no sintagma "teoria queer", inicialmente pela feminista italiana Teresa de Lauretis. (SAFATLE, 2015, p. 178).?

\footnotetext{
5 Die Dissonanzen, die sie schrecken, reden von ihrem eigenen Zustand: einzig darum sind sie ihnen unerträglich (ADORNO, 1977, p. 18). Nelson Rodrigues, em o beijo no asfalto, descreveu o mecanismo de autojustificativa que trabalha na mente dos paladinos do moralismo, moralismo esse que se alimenta do ódio que sentem por seu próprio desejo proibido.

6 O adjetivo anglo-saxônico quer vem do alto-alemão médio (Mittelhochdeutsch) twer, qwer, e, antes disso, do alto-alemão antigo (Althochdeutsch) thwerah e do germano *pwerha-; aparece em documentos desde o século IX, e significa transversal, atravessado.

FIGUEIREDO, Euridice, p. 4
} 


\section{$4 / 18$}

Veritas, Porto Alegre, v. 66, n. 1, p. 1-18, jan.-dez. 2021 | e-39063

O Cristianismo nasce num contexto cultural profundamente queer. O ambiente grego, que permeava o mundo cultural da Palestina do século I, estava muito distante da arte idealista e metafísica do século de Péricles, do Discóbolo de Míron ou do Apolo do Belvedere. Queer define a arte helenistica: está no altar de Pergamon (Figura 1), está no grito do Laocoonte ${ }^{8}$ (Figura 2), na mistura de estilos, no acavalamento de técnicas e de divindades: o sarcófago paleocristão do romano Junius Bassus (Figura 3), talvez a obra de escultura mais importante dos primeiros séculos, representa Jesus junto com os apóstolos Pedro e Paulo e, junto, sem pejo algum, o deus pagão Urano, nome grego para o céu.

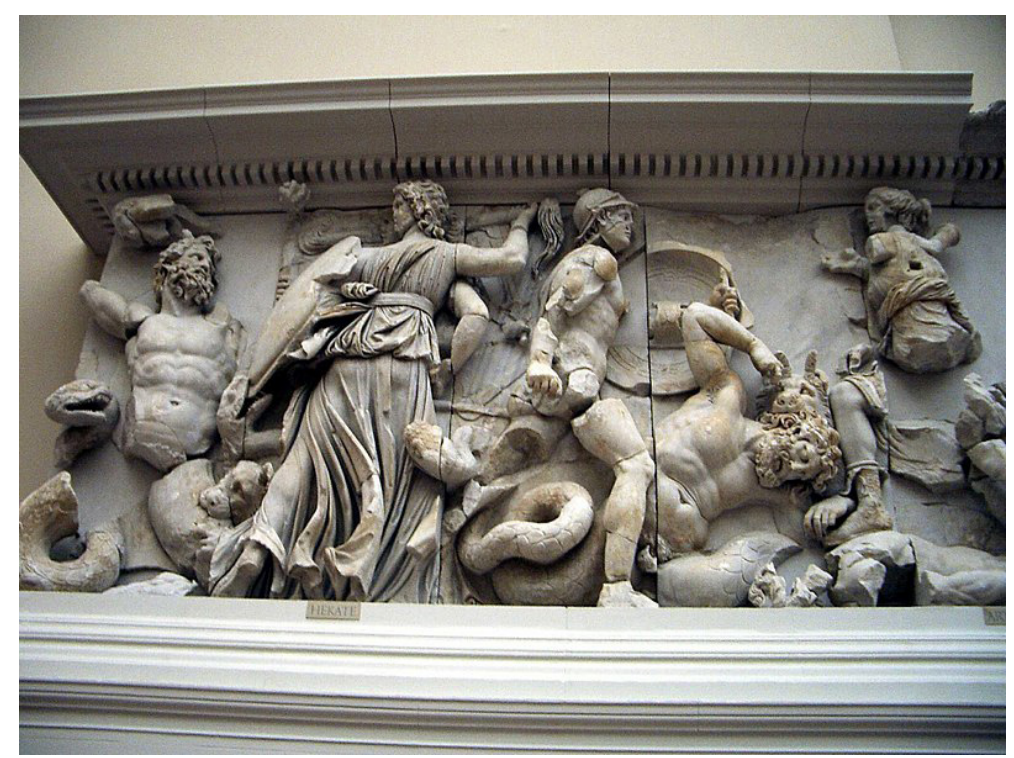

Figura 1 - Altar de Pergamon, séc. II a.C. Disponivel em: https://pt.wikipedia.org/wiki/ Ficheiro:Pergamonmuseum_-_Antikensammlung___Pergamonaltar_02-03.jpg

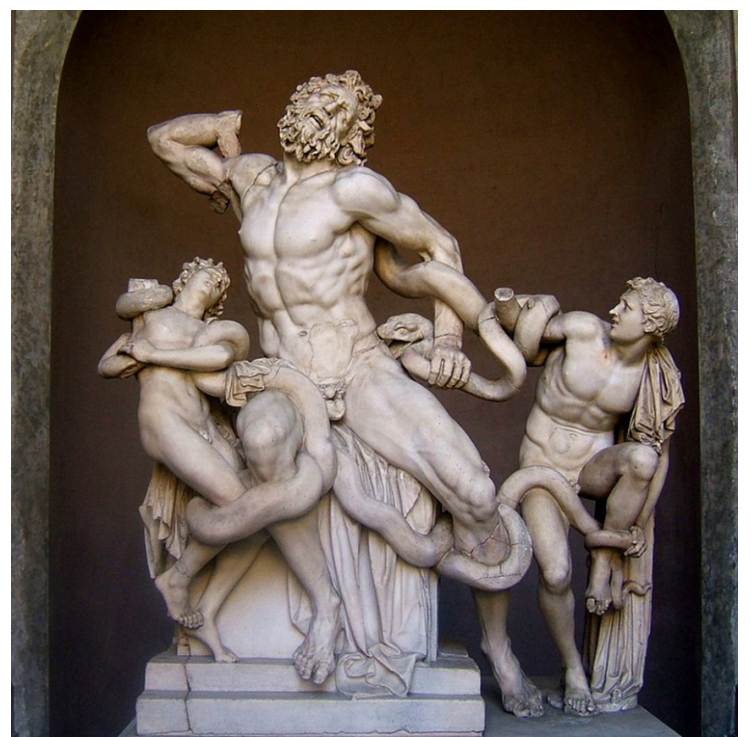

Figura 2 - Laocoonte e seus filhos. Atribuido a Agesandro, Atenodoro e Polidoro. 27 a.C. Por JuanMa - Obra do próprio, CC BY-SA 3.0. Disponível em: https://commons.wikimedia.org/w/index.php?curid $=476356$

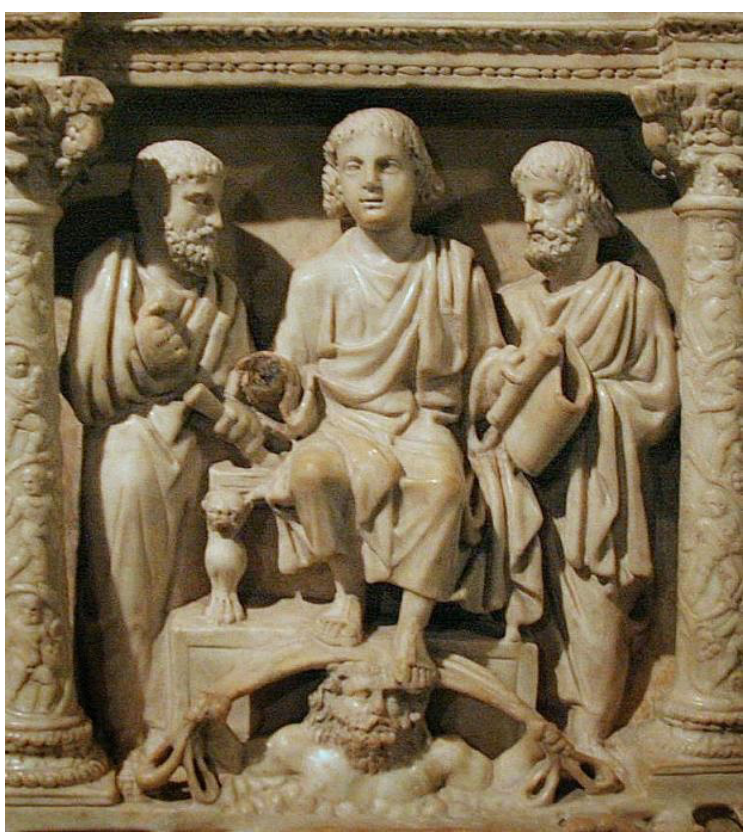

Figura 3 - Cristo como filósofo - sarcófago de Junius Bassus, séc. IV. Disponivel em: https://temasycomentariosartepaeg.blogspot.com/p/blog-page_217.html

8 Ver LESSING, G. E. Laocoonte ou sobre as fronteiras da pintura e da poesia: com esclarecimentos ocasionais sobre diferentes pontos da história da arte antiga. Introdução, tradução e notas Márcio Seligmann-Silva. São Paulo: Iluminuras, 1998. 
É certo que, desde seus primórdios, a arte cristã precisou se equilibrar entre dois polos: a anicônica tradição hebraica, que ordenava: "Não fabricarás imagens..." (Ex. 20,4; Lev. 19,4; 26,1; Dt. 4,15-20; Sab. 15,4-5) e a fé na encarnação do Verbo, na nova aliança, no Evangelho, como aponta S. João: "Felipe, quem me vê a mim, vê o Pai... Não acreditas que eu estou no Pai e o Pai está em mim?" (Jo 14, 8-10). Mas, essa tensão constituiu, em parte, o motor a impulsioná-la. Para onde? Para frente, no tempo: o triunfo do conceito de temporalidade unidirecional foi fruto do trabalho do apóstolo João e da literatura apocalíptica. Se a flecha do tempo não progredisse sempre em uma única direção - o futuro -, não se poderia cumprir a vinda do paráclito, como prometido por Jesus (Ver Jo, 14, 16). João superou as concepções circulares orientais de temporalidade e fabricou um "telos" cristão para a nova era que se iniciava. Assim, as próprias ideias de progresso e de passagem do tempo têm raizes na literatura apocalíptica e são, culturalmente, teológica e filosoficamente, conceitos cristãos ${ }^{9}$.

Por isso, também o indivíduo cristão é queer; ele é uma criatura de passagem, tornando-se, a cada instante, aquilo que ele é. Os pais da Igreja tiveram de lutar muito para distanciar o Cristianismo do fatalismo das religiões orientais. O cristão deveria ser um indivíduo que age no mundo - caso contrário, não seria possivel construir o reino de Deus e preparar a parusia -, o cristão é a corda estendida sobre o abismo, um indivíduo constantemente a se tornar, ele nunca "é", num sentido metafísico e imutável, sempre "será".

\section{Símbolo, feiúra e miscigenação}

A arte paleocristã dos primeiros séculos serviu-se da linguagem simbólica para contornar a advertência dos líderes e profetas do Antigo Testamento, em relação à fabricação de ima-

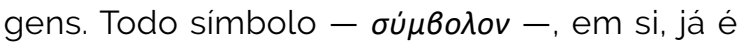
uma construção hibrida, transversal; o vocábulo grego significa sim- (junto) e -balein (lançar); portanto, juntar duas partes que estavam separadas: objeto e seu significado figurado. Só é possivel compreender o simbolo quando se possui a chave do signo. O emprego de símbolos foi expressamente recomendado pelos pais da Igreja, como Clemente de Alexandria. Essa recomendação foi seguida pelos artistas dos primeiros séculos: a mitologia pagã foi transformada e adaptada para derivar significação cristã (o mito de Perséfone como alegoria da ressurreição e o semideus Hércules como Bom Pastor são apenas os exemplos mais conhecidos). Da carta do Papa Gregório Magno ao bispo Sereno, de Marselha, Besançon destaca que:

[...] pelo fato de a imagem persuadir os pagãos
a entrar na fé e não sair dela, é mantido um
elo com as imagens diante das quais eles
prestavam um culto outrora idólatra. Tudo
o que foi adquirido em matéria de arte, as
formas, as matérias, as técnicas e o ofício, é,
portanto, reutilizável. Tudo [...] é acolhido na
nova economia e nela encontra o seu lugar.
(BESANÇON, 2002, p. 4).

Séculos mais tarde, essa prática continuava a dar frutos: na Irlanda do século VIII, os monges copistas emularam o geometrismo da iconografia tradicional celta, a ourivesaria e os padrões decorativos dos vikings. Em vez do eikonos, acentuou-se o decorativismo abstrato. Os iluministas irlandeses representaram, de forma esquemática, animais totêmicos dos cultos pagãos celtas, com predomínio do mágico sobre o cristão. Os Livros de Kells (Figura 4), de Durrow (Figura 5) e o Evangelho de Lindisfarne (Figura 6) são seus exemplos mais evidentes.

9 Em T.S. Elliot é possivel encontrar uma extensão do conceito joanino de tempo: "Time present and time past / Are both perhaps present in time future / And time future contained in time past." (SPENCER, 2008, p. 224). 


\section{$6 / 18$}

Veritas, Porto Alegre, v. 66, n. 1, p. 1-18, jan.-dez. 2021 | e-39063

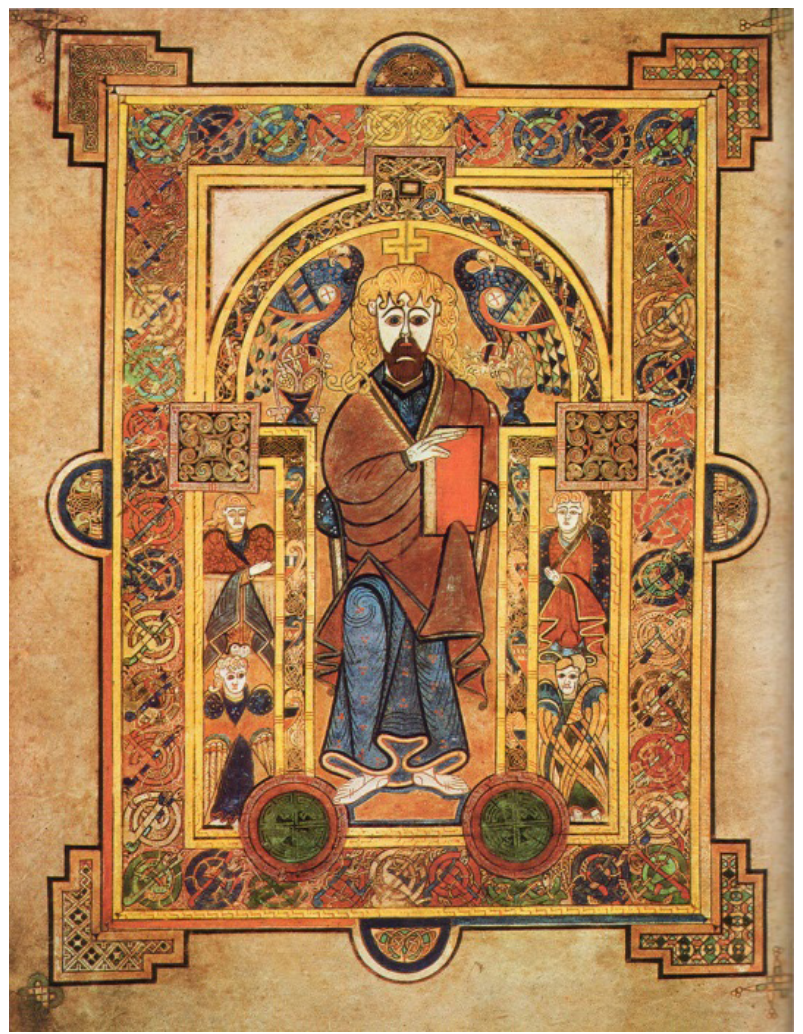

Figura 4 - Livro de Kells, cca. 800. Domínio público. Disponivel em: https://commons.wikimedia.org/w/ index.php? curid $=44527$

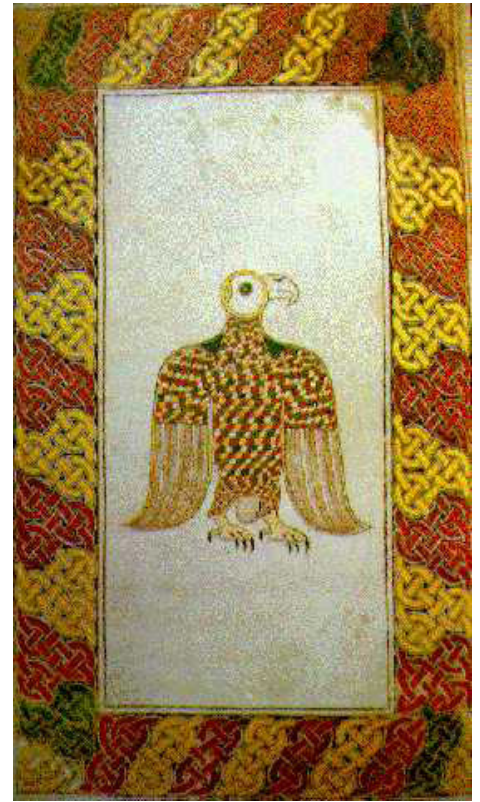

Figura 5 - Livro de Durrow, cca. 680. Dompinio público. Disponivel em: https://commons.wikimedia. org/w/index.php? curid $=304580$

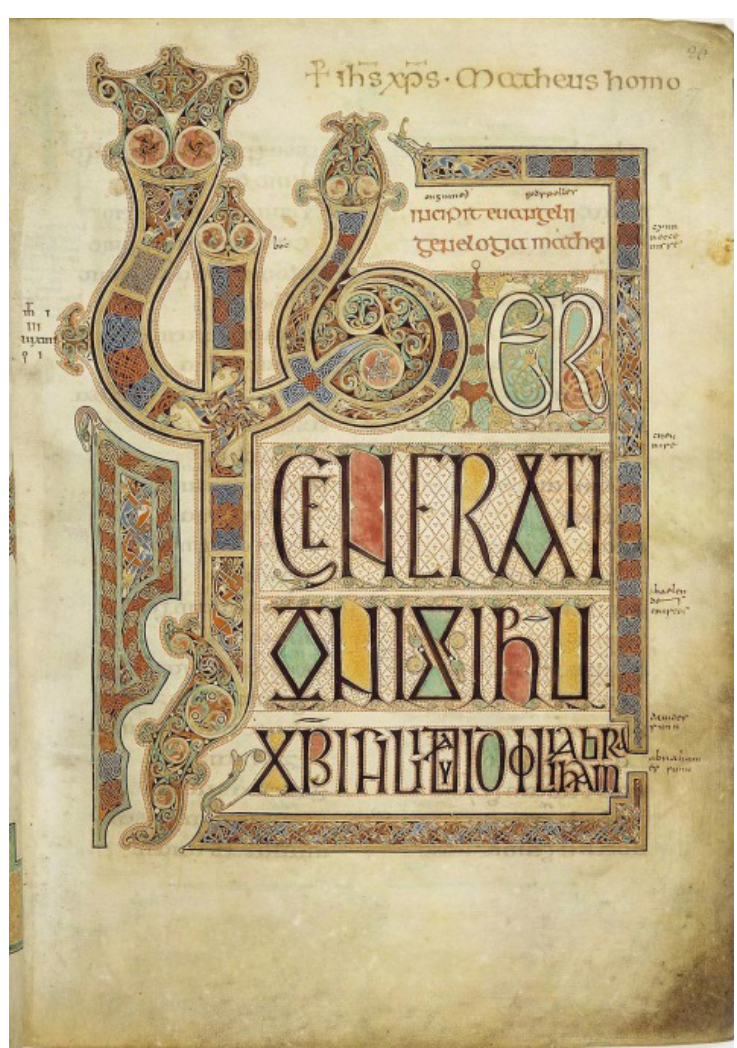

Figura 6 - Evangelho de Lindisfarne. séc. VII. By Eadfrith of Lindisfarne (presumed) Public Domain. Disponivel em: https://commons.wikimedia.org/w/ index.php?curid=196226 
Na Europa continental, sob Carlos Magno, o processo é o mesmo: acontece uma fusão do espírito celta-germânico com a arte mediterrânea.
Carlos Magno manda vir de Roma um sarcófago pagão, no qual deseja ser sepultado (Figura 7).

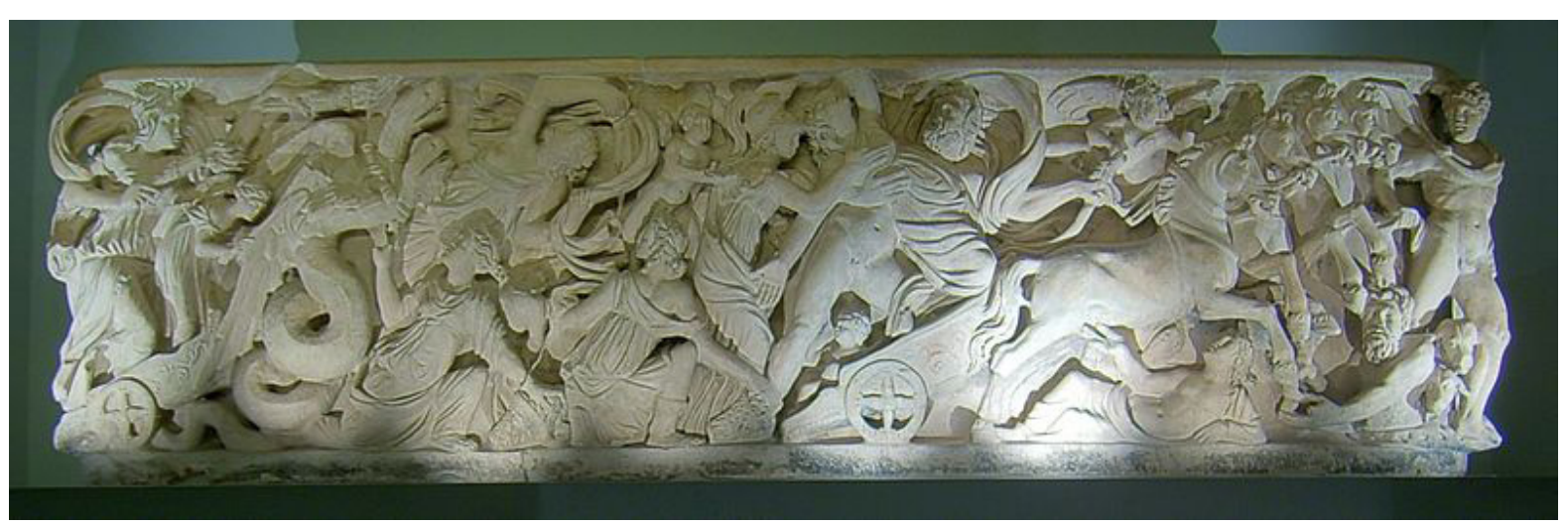

Figura 7 - Sarcófago de Carlos Magno, cca. 180. Disponivel em: https://commons.wikimedia.org/wiki/ File:AachenerDomSarg.jpg? uselang=de

O mito clássico de Perséfone, esculpido a alto relevo no sarcófago de Carlos Magno, com a história de morte e ressurreição, é um sinal político: eis aqui o herdeiro do antigo Império Romano, um rei franco convertido, que agora é o senhor de um novo império, o Sacro Império Romano Germânico.

Num certo sentido, o ataque moralista à exposição de Porto Alegre é um eco anacrônico da querela das imagens; já, naquela vez, o objetivo fora político: desviar a atenção da sociedade das transformações profundas que estavam ocorrendo em seu seio. Os iconoclastas de Bizâncio do século VIII visavam dar coesão ao império, rodeado pelo aniconismo islâmico, e frear o poder dos monges - com o objetivo de apoderar-se das riquezas dos mosteiros, o que efetivamente aconteceu. Como não há sociedade totalmente homogênea - sonho de todos os totalitaristas -, o recurso à demonização moralista do outro é a ferramenta mais prática. Os escritos de Astério de Amásia (século IV), que nunca fora iconoclasta, e sim um defensor do realismo artístico, foram distorcidos pelo Patriarca João VII, o Gramático, de Constantinopla, para fomentar histeria na população - as reais intenções eram político-econômicas: reprimir o movimento monástico em prol de uma maior centralização das decisões públicas - o que hoje se chamaria de golpe palaciano para instauração de uma ditadura velada.

É preciso, nesse ponto, voltar às obras do Queermuseu, que causaram incômodo por razões religiosas. São elas, principalmente: "Cruzando Jesus Cristo com Deusa Shiva" (1996), de Fernando Baril, e "Et verbum..." (2011), de Antônio Obá. Essas não são obras de arte sacras, no sentido estrito do termo, é certo. Mas, assim também não o eram O carro de Feno (Hooiwagen-drieluik, 1490), do holandês Hieronymus Bosch (Figura 8), ou o Réquiem, de Giuseppe Verdi (1874), com suas inflexões sensualistas, entre incontáveis outras. 

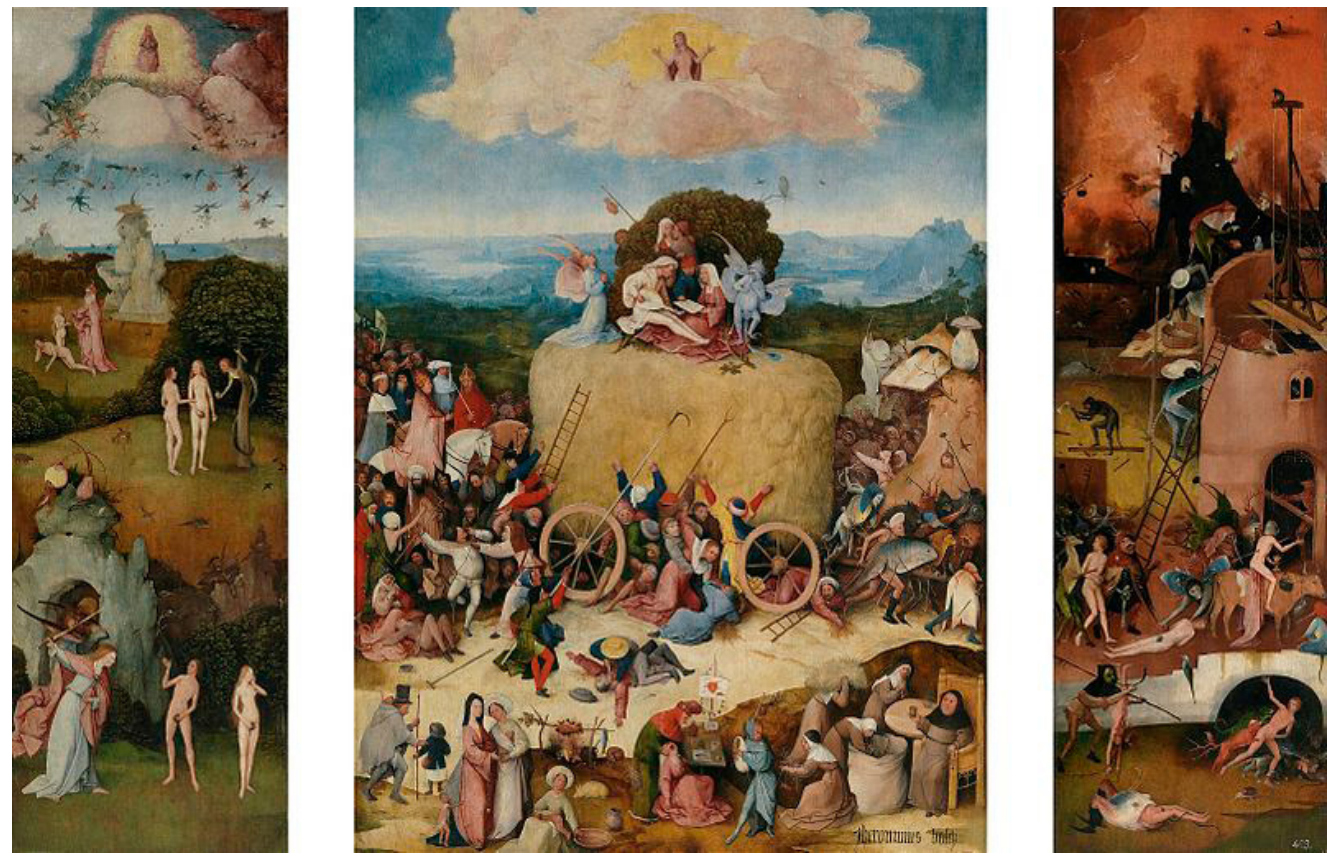

Figura 8 - Hieronimus Bosch: O carro de feno, cca. 1516. Disponivel em: https://pt.m.wikipedia.org/wiki/ Ficheiro:The_Hay_Wain_by_Hieronymus_Bosch.jpg

Assim como o triptico de Bosch e a composição de Verdi dialogam de forma crítica com a sociedade em uma era de importantes mudanças na política europeia, as obras escolhidas pelo curador Gaudêncio Fidelis para integrar a exposição são, também, capazes de propor - e provocar - reflexões criticas ${ }^{10}$. Em Bosch, as criaturas hibridas, meio humanas, meio plantas ou animais, são a expressão de sua época: a feiúra é parte da denúncia da agressão cometida pela humanidade contra o mundo criado. A feiúra, na arte cristã, tem uma tradição muito longa, cujas manifestações mais conhecidas são as gárgulas das igrejas góticas - as da catedral de Notre Dame, de Paris, são quase um ícone pop. Uma leitura da Summa, de Alexandre de Halles (século XIII), demonstra que a arte cristã nunca procurou isolar-se num reino de coisas apenas belas, e que a feiúra também tem seu lugar no mundo:

O mal enquanto tal é disforme... Contudo, como do mal se desenvolve o bem, é chamado bem porque com o bem confere, e, assim, na ordem, é belo. Portanto, não é considerado belo de modo absoluto, mas belo na ordem; aliás, seria preferivel dizer: a própria ordem é bela. (HALLES apud ECO, p. 149).
A noção inclusivista de ordo (ordem) da filosofia medieval cristã mostra-se precursora da estética e da ética pós-modernas, com seus múltiplos platôs de coexistência de opostos. Ela foi preparada por um filósofo cristão, que viveu na fronteira entre o mundo clássico antigo e o medieval: Agostinho de Hipona (354-430). Na Cidade de Deus, Agostinho (apud ECO, p. 147) escreve: "Também os monstros são criaturas divinas e, de algum modo, pertencem, eles também, à ordem providencial da natureza". A partir da mediação do conceito de congruentia, beleza e feiúra concorrem para compor a imagem do mundo.
Der Ansicht, dass alles Seiende gut und wahr ist, steht die Erfahrung des konkreten Übels von Krankheit, Schmerz, körperlicher Entstellung, Krieg und Lastern gegenüber. Nach Augustinus ist der Urheber dieses Übels der sündige Mensch, er ist für das Böse und Hässliche selbst verantwortlich. Es dient für inn als Strafe, Probe und Mahnmal. Über den Begriff der congruentia, dem Verhältnis der einzelnen Teile zueinander, finden sich schönes und hässliches zu einem Welbild zusammen. Über die Proportion und vor allem über den Kontrast fügt sich folglich auch das Hässliche in die Harmonie der Welt ein, es hat einen Existenzgrund innerhalb der göttlichen Schöpfungsordnung. (OSTER, 2014, p. 118).

10 O termo queer não se aplica exclusivamente à sexualidade, mas é preciso lembrar que também, hoje, a sociedade passa por um tempo de transição: já são vários os paises que reconhecem oficialmente três e até mais gêneros: Paquistão, İndia, Bangladesh, Indonésia (cinco gêneros), Alemanha, Austrália etc. 
A inclusão da feiúra na arte cristã terá, na teologia negativa do Pseudo-Dionísio Areopagita (século VII), fundamentação teórica mais original. Duas obras, Hierarquia celeste e Nomes divinos, serão os documentos mais importantes do periodo patrístico da Igreja para estabelecer a importância do papel das imagens e dos símbolos como mediadores do conhecimento de Deus e da transmissão da fé. O Areopagita acreditava que, entre Deus e o mundo, não era possivel nenhuma semelhança no sentido estrito. Em função disso, o símbolo não deveria permitir nenhuma identificação entre o que ele é e o que ele significa. Ele recomendou, então, o emprego de símbolos "dissemelhantes". O objetivo: não permitir que os fiéis se enganassem pensando, por exemplo, que Deus pai seja, realmente, um velhinho de barbas brancas, sentado num trono sobre as nuvens. Para evitar esse autoengano, seria necessário pintar não o que Deus "é" - coisa que não é dado aos humanos conhecer -, mas tudo o que ele "não é" (não é finito, não é limitado etc). De acordo com essa estética revolucionária, a extrema beleza poderia ser expressa pela extrema feiúra. É por isso, também, que Tertuliano e Orígenes advogavam a representação de um Cristo feio fisicamente ${ }^{11}$. Pela abordagem negativa, e graças à feiúra, o espirito do espectador, em vez de aderir ao símbolo, é projetado em direção ao seu contrário, à "ideia" pura de Deus. As teorias do Areopagita mesclam o Neoplatonismo de sua época com o sincretismo das religiões de mistérios pagãs, com sua concepção do segredo e do velamento na ordem simbólica.

Mais tarde, Hugo de S. Vitor (1096-1141) extrairia, dessa teoria, um sistema e um método exegético, que influenciaria a arte cristã e toda a arte ocidental pelos séculos seguintes. Os capitéis românicos ${ }^{12}$, com seu irrealismo simbólico e fantástico de criaturas imaginárias e as gárgulas das catedrais góticas, são herdeiros da estética negativa do Pseudo-Dionísio. Encontra-se, nesse ponto, o fundamento do papel das imagens e dos simbolos como mediadores de conhecimento. $\mathrm{Na}$ medida em que a hierarquia celeste é perpassada por uma luz divina, cada um pode dela participar, em função de suas próprias forças. Essa luz reflete-se nos simbolos e nas imagens acessiveis ao olhar; mas isso ainda não é um conhecimento da divindade. É apenas por meio do uso que se faz da imagem que se torna possivel expressar a relação do homem com Deus. Entre Deus e o mundo, portanto, não é possivel nenhuma semelhança no sentido estrito. A recomendação do Areopagita, de usar símbolos dissemelhantes - já que o símbolo não deve permitir nenhuma identificação entre o que ele é e o que ele significa - , exerceria forte influência sobre as teologias mistica e a estatuária medieval.

\begin{abstract}
Para livrar de um tal perigo aqueles cuja concepção de beleza jamais ultrapassou o grau de uma beleza material, a grande sabedoria dos escritores sagrados decidiu de um modo sublime usar metáforas sem qualquer semelhança com seu modelo. Desse modo, domando nossa tendência às coisas materiais e imagens torpes, elevando ao mesmo tempo aquela parte de nossa alma que tende às alturas e, pela própria estranheza dessas metáforas, não permitindo que mesmo os seres mais inclinados à materialidade possam ser julgados como possiveis ou reais e que os milagres celestes possam guardar qualquer semelhança com as coisas mundanas. Não esqueçamos ainda que nada há que não participe do Bem, pois, em verdade, falaram as Escrituras: "Todas as coisas excedem em beleza". ${ }^{33}$ (PSEUDO-DIONISIO apud LICHTENSTEIN, 2004, p. 24).
\end{abstract}

Fica, assim, refutado o mito da arte cristã apenas bela, caudatário de outro, mito de raízes neoplatônicas, estudado pelo pensador polonês Zygmunt Bauman: o mito da pureza ${ }^{14}$. Bauman (1998) observa que a pureza não existe na natureza - ela é fruto do pensamento metafísico. Esse pensamento transferiu-se para o contexto cultural humano por meio de um processo depravado de darwinismo social. Disso, teria nascido

\footnotetext{
11 Mas S. Crisóstomo e S. Jerônimo sustentavam a tese de que Jesus era belo fisicamente. Ver o texto de Urs von Balthasar (em francês) http://www.assomption.org/fr/mediatheque/revue-itineraires-augustiniens/itineraires-augustiniens-ndeg31-la-beaute/ii-augustin-maitre-spirituel/le-christ-est-il-beau-par-urs-von-balthasar.

12 Por exemplo, em St. Benoît sur Loire e St. Lazare de Autun.

13 PSEUDO-DIONISIO AREOPAGITA, A origem divina das imagens, em: LICHTENSTEIN, Jacqueline. A pintura, Vol. 2: A teologia da imagem e o estatuto da pintura. São Paulo: Editora 34, 2004.

14 Ver BAUMAN, Zygmunt. O mal-estar da pós-modernidade. Rio de Janeiro: Jorge Zahar Ed., 1998.
} 
a glorificação da pureza como necessidade histórica. Ademais de purezas, como a racial - do nazismo - e social - do estalinismo - ela pode também ser estética, religiosa, de gênero etc. A pureza não suporta o resíduo. Hannah Arendt (1993, p. 112) identifica esse resíduo social como o pária: primeiro, ele adere ao judeu e, depois, 0 conceito vai migrando para outros grupos sociais e assumindo sucessivos avatares. Uma de suas expressões mais conhecidas é a exposição que o ministro nazista Goebbels, da propaganda, organizou, em 1937, a que chamou de Arte Degenerada ${ }^{15}$ (Entartete Kunst). Nela, expuseram-se obras que não correspondiam ao ideal de pureza estética do Terceiro Reich: do expressionismo, impressionismo, cubismo etc. Toda arte não bela seria, assim, degenerada (entartet) e mereceria a destruição. O nazismo provou que, quando se começam a queimar livros e obras de arte, está-se a um passo de se queimarem pessoas.

Um outro mito afirma que o mal, a feiúra e o vício são alienigenas à $a r t e^{16}$. Esse curioso pensamento é herdeiro da teoria dos homens de metal - ouro, prata e bronze - de Platão. Por obra de um Neoplatonismo pervertido, deriva-se a convicção da exterioridade da feiúra a tudo o que se relacione com arte e, no caso deste artigo, com arte cristã. A teoria do Pseudo-Dionisio Areopagita a esse respeito já foi explicada anteriormente, mas a persistência do mito parece querer reviver um clássico problema estético medieval: deve-se pintar o diabo com arte (belamente) ou sem arte, de forma feia? Tudo sugere que a ortopedia moral que agrediu a exposição Queermuseu imagina-se potente bastante para curar gays, garantir escolas sem partido e expulsar do mundo toda arte degenerada. O mal que vem de fora, contudo, faz parte do imaginário superado de um mundo pré-Maquiavel; é a mentalidade das Cruzadas, um dos capítulos mais inglórios da lgreja e de toda a história do Ocidente. Do mito de que o mal seja exterior e, que, portanto, só do exterior possam derivar coisas ruins, vem o temor de que a arte degenerada possa provocar a degeneração, de que a arte ofensiva à mentalidade dos cristãos possa afastá-los de Deus, de que se possam aliciar as dóceis mentes juvenis, de que o indefeso povo brasileiro possa ser doutrinado pelo satânico esquerdismo ateu - e já não faltam editoriais desse feitio na grande imprensa brasileira. A aplicação desse principio à arte cristã faria, por exemplo, proibir a representação da paixão, sob o pretexto de ser uma incitação à agressão: a denúncia da tortura expressa pelo vir dolorum ${ }^{17}$ permutar-se-ia, aqui, por apologia à tortura! É preciso frisar: as criações de um artista não são afirmações apologéticas, são questionamento e convite à reflexão.

\section{Verfransung der Künste (enodamento das artes) e o processo do material}

O conceito de Verfransung der Künste - enodamento das artes -, cunhado por Theodor Adorno, refere-se ao substrato comum que as artes possuem; esse substrato une todas as suas manifestações na categoria da linguagem, o que tem por consequência um longo e constante processo de aproximação de seus significados. As franjas (Fransen) devem ser entendidas, aqui, como a face visivel dos objetos, a parte que avança e invade outros campos do existir. O Verfransung - o enodamento, ou superposição - apresenta-se como uma previsão das diferentes direções tomadas pela arte pós-moderna; ela abre a possibilidade de um diálogo entre a filosofia da arte e as práticas contemporâneas de criação. A partir daí, surge a possibilidade de assimilar objetos do mundo fisico - como, por exemplo, construções que existam exteriormente à esfera estética -, possibilidade essa que se confirma na mestiçagem de técnicas e personagens, cultivada pela arte cristã desde seus primórdios. A partir desse conceito adorniano, tornar-se-ia possivel permitir à arte tomar

\footnotetext{
15 Nas palavras do poeta e dramaturgo nazista Hanns Johst (1933): "Quando ouço falar em 'cultura', destravo meu revólver" "Wenn ich Kultur höre ... entsichere ich meine Browning!"

${ }_{16}$ A narrativa unitária é de que a verdadeira arte é apenas bela, é edificante, e disso vem seu poder de atração; nesse caso, contudo, os vasos gregos com representações priápicas e das festas falofórias - que estão no Louvre - e as tumbas etruscas teriam de passar a partir da racionalista iniciativa gaúcha, a figurar nos manuais das patologias, junto com o comunismo, o socialismo e o judaísmo - por que não? É preciso ter em mente que o mito da pureza é filho do sonho totalitarista, o qual não conhece limites.

17 Homem das dores. Ver Isaías 53, 3-6.
} 
parte no mundo sem a necessidade de imitá-lo. Participar do mundo sem o imitar preserva, para a obra de arte, seja ela cristã ou não, a possibilidade de seguir desenvolvendo seu potencial crítico, mesmo que esta admita a inclusão de materiais históricos pregressos.

O enodamento das artes, inimigo de um ideal de harmonia, e que, por assim dizer, pressupõe relações ordenadas no interior dos gêneros como garantia de sentido, desejaria escapar ao aprisionamento ideológico da arte, aprisionamento esse que se estende até sua constituição como arte como esfera autárquica do espirito. É como se os gêneros artísticos, ao negar o delineamento claro de sua forma, se pusessem a roer o próprio conceito de arte. O princípio de montagem, que surgiu após a primeira grande Guerra por meio da explosão do Cubismo e - totalmente independente disso - por meio de experimentadores como Schwitters e também do Dadaísmo e do Surrealismo, foi a manifestação primeira do enodamento das artes ${ }^{18}$. (ADORNO, 1977. p. 450 , tradução minha).
Ao longo da milenar história da construção da estética cristã, com seus raros momentos de retrocesso ou estagnação, a lgreja estimulou e financiou não apenas a arte e os artistas mais ousados. Ela manteve-se sempre aberta à assimilação, à inclusão de elementos externos ao Cristianismo. Em outras palavras, aberta ao não puro. Ademais dos exemplos já arrolados da arte tumular paleocristã e dos iluministas irlandeses, recorde-se aqui brevemente: no Românico dos séculos $X$ a XIII, a síntese do construtivo e do decorativo - veja-se o Portal da Glória, do mestre Mateus, na catedral de Santiago de Compostela (Figura 9) ou o pórtico de Sainte Madeleine de Vezelay (Figura 10) - que apontam para a superação da dicotomia rigida entre as camadas diferentes de linguagem, que concorrem para a constituição material de uma obra de arte.

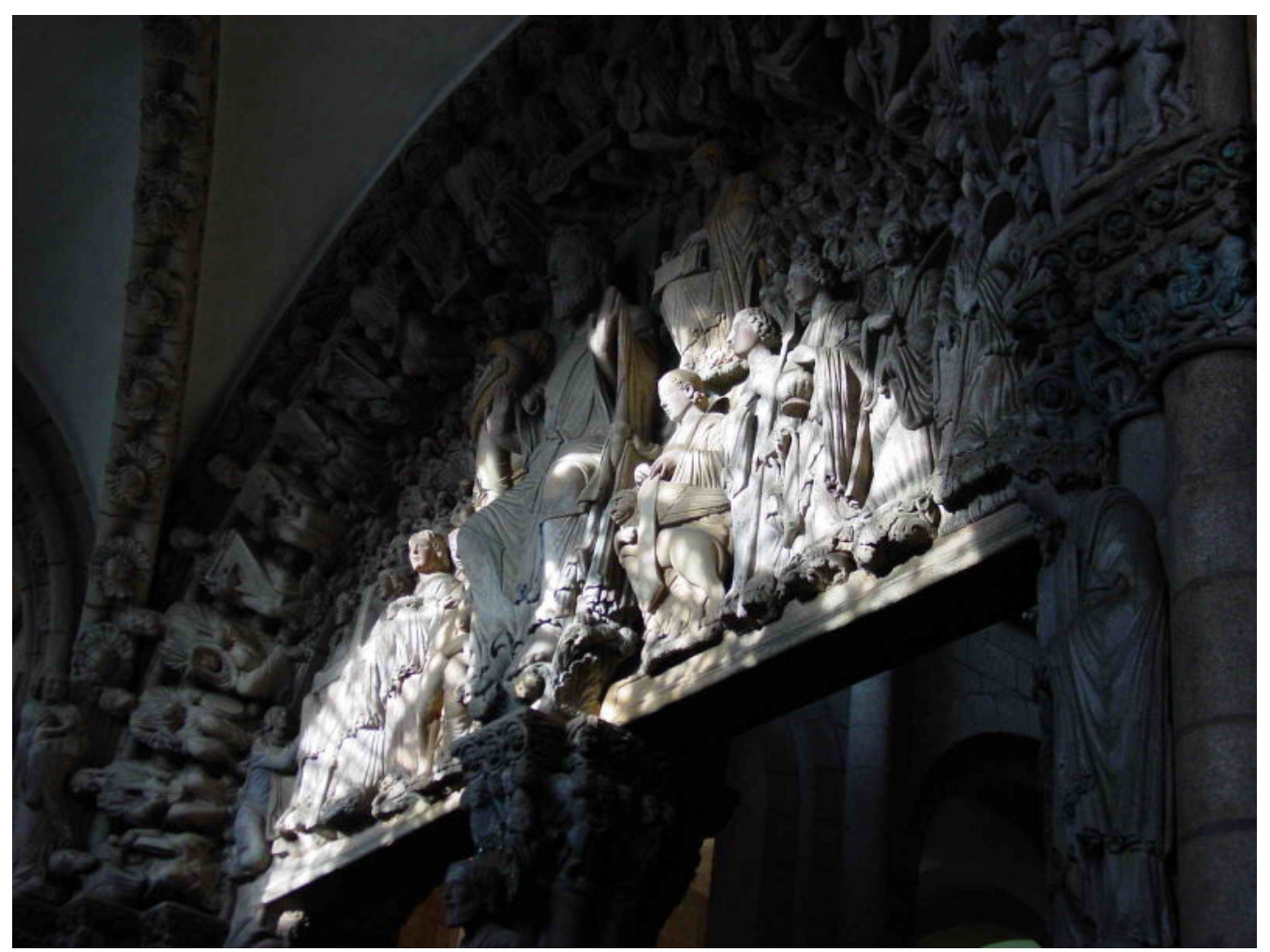

Figura 9 - Mestre Mateus: Portal da Glória - Catedral de Santiago de Compostela. cca. 1168. Por Luis Miguel Bugallo Sánchez (Lmbuga Commons) (Lmbuga Galipedia). Publicada por: Luis Miguel Bugallo Sánchez — Obra do próprio, CC BY-SA 3.0. Disponivel em: https://commons.wikimedia.org/w/index.php?curid=317187

18 Do original: Die Verfransung der Künste, feind einem Ideal von Harmonie, das sozusagen geordnete Verhältnisse innerhalb der Gattungen als Bürgschaft von Sinn voraussetzt, möchte heraus aus der ideologischen Befangenheit von Kunst, die bis in ihre Konstitution als Kunst, als einer autarkischen Sphäre des Geistes, hinabreicht. Es ist, als knabberten die Kunstgattungen, indem sie ihre festumrissene Gestalt negieren, am Begriff der Kunst selbst. Urphänomen der Verfransung der Kunst war das Montageprinzip, das vor dem Ersten Krieg in der kubistischen Explosion und, wohl unabhängig davon, bei Experimentatoren wie Schwitters und dann im Dadaismus und im Surrealismus hochkam. 


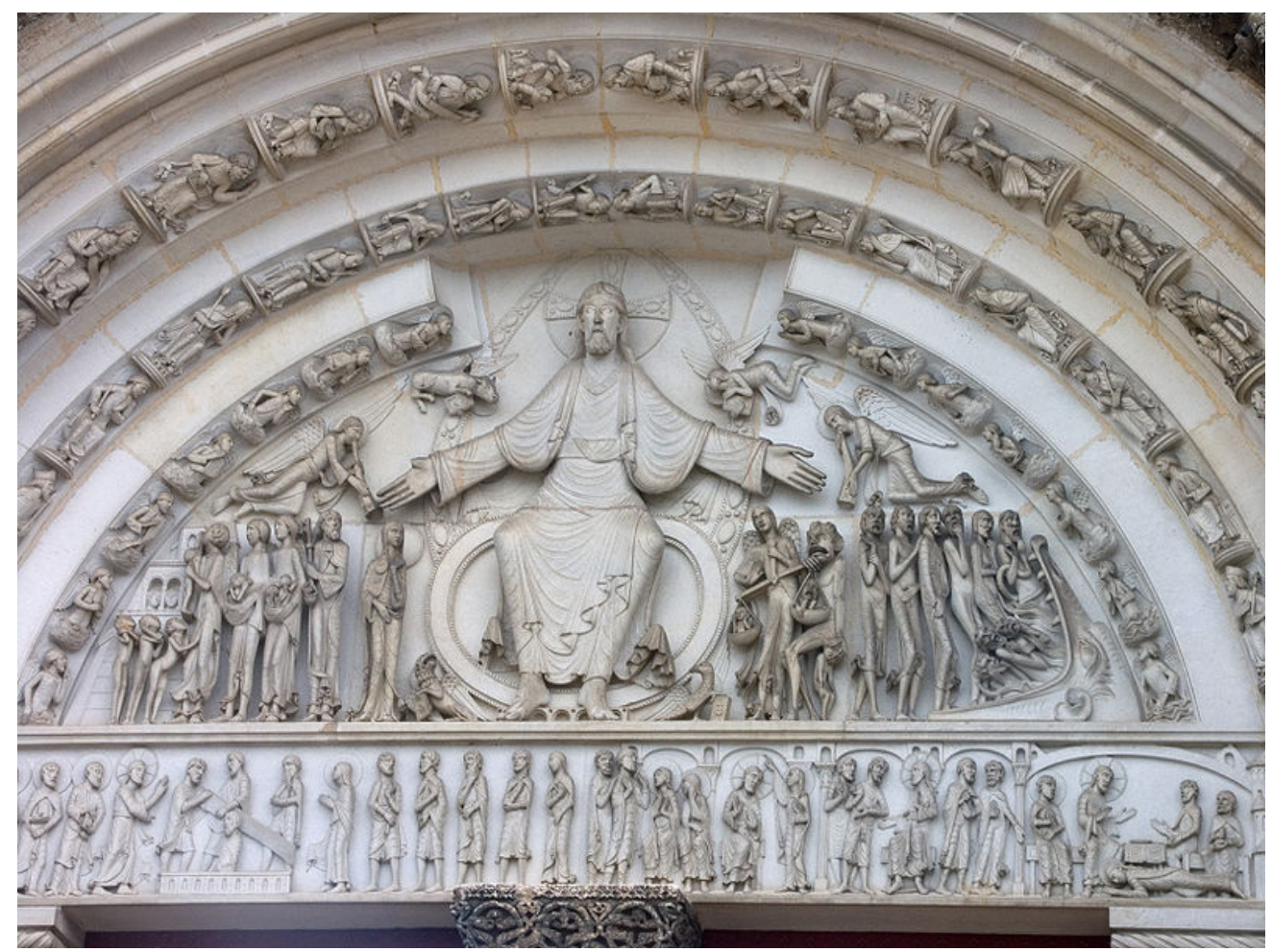

Figura 10 - Igreja de Santa Maria Madalena em Vezelay - pórtico, cca. 1120. Por Jean-Christophe Benoist Trabalho pessoal, CC BY 2.5. Disponivel em: https://commons.wikimedia.org/w/index.php?curid=2066329

No gótico dos séculos XIII a XV, a aplicação consequente das teorias do Pseudo-Dionísio Areopagita: gárgulas e monstros - o feio, 0 impuro - passaram a habitar catedrais e claustros. No Renascimento, que Umberto Eco chamou de religião da beleza, retorna com força o sincretismo: na arquitetura, a construção de templos pagãos cristianizados; nas esculturas, a evocação de deuses e heróis do Olimpo na figura de santos e mártires. No Renascimento, também o jogo de ilusões óticas, superando a dicotomia platônica entre matéria e ideia, aponta para uma estética sem preconceitos: o ilusório já vinha sendo empregado de forma ancilar em pinturas desde a época paleocristã, mas é a perspectiva aperfeiçoada por Filippo Bruneleschi (1377-1446), que dominará a arte, e não só a arte cristã, por 400 anos. Bruneleschi, o arquiteto da cúpula de St. Maria dei Fiori, em Florença, resolveu o problema de como cobrir a maior cúpula, até então construida na Cristandade - de 45m de diâmetro por 91m de altura -, quando aplicou, àquele templo cristão, cânones dos templos pagãos antigos (Figura 11).

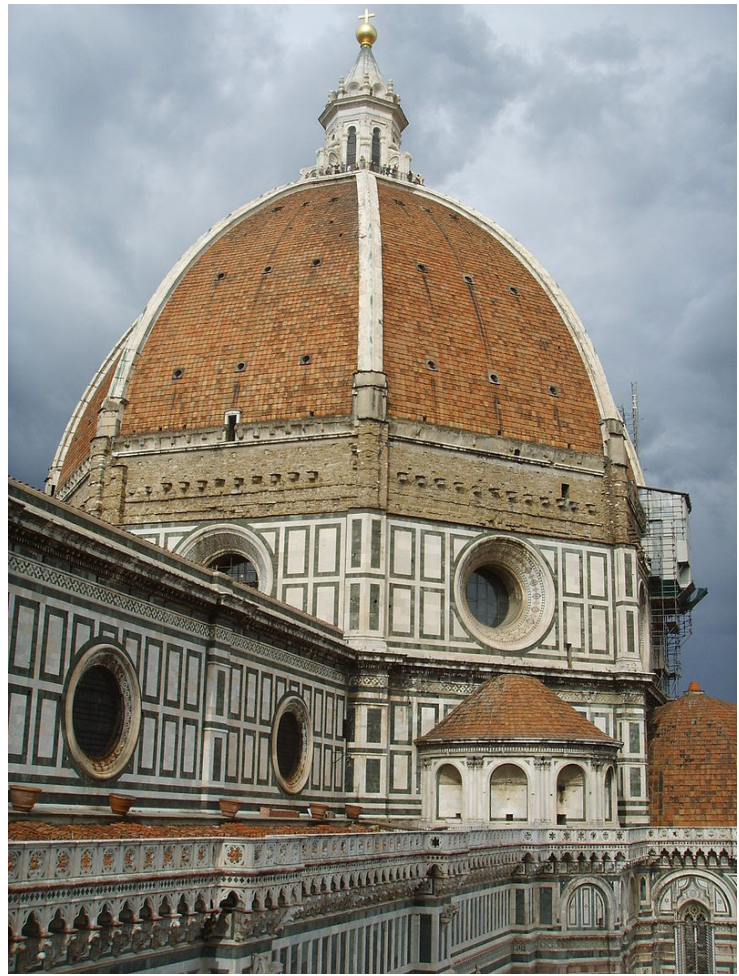

Figura 11 - Filippo Brunelleschi: Santa Maria das Flores, Florença, 1436. Por Sailko - Fotografia autoproduzida, CC BY 2.5. Disponivel em: https://commons. wikimedia.org/w/index.php? curid $=2225958$ 
Pouco antes dele, Giotto da Bordone, com suas figuras que parecem furar a tela em direção ao espectador e sua técnica da giornata de pintar os afrescos, foi precursor na criação de ilusões de multidimensionalidade no espaço plano (Figura 12).

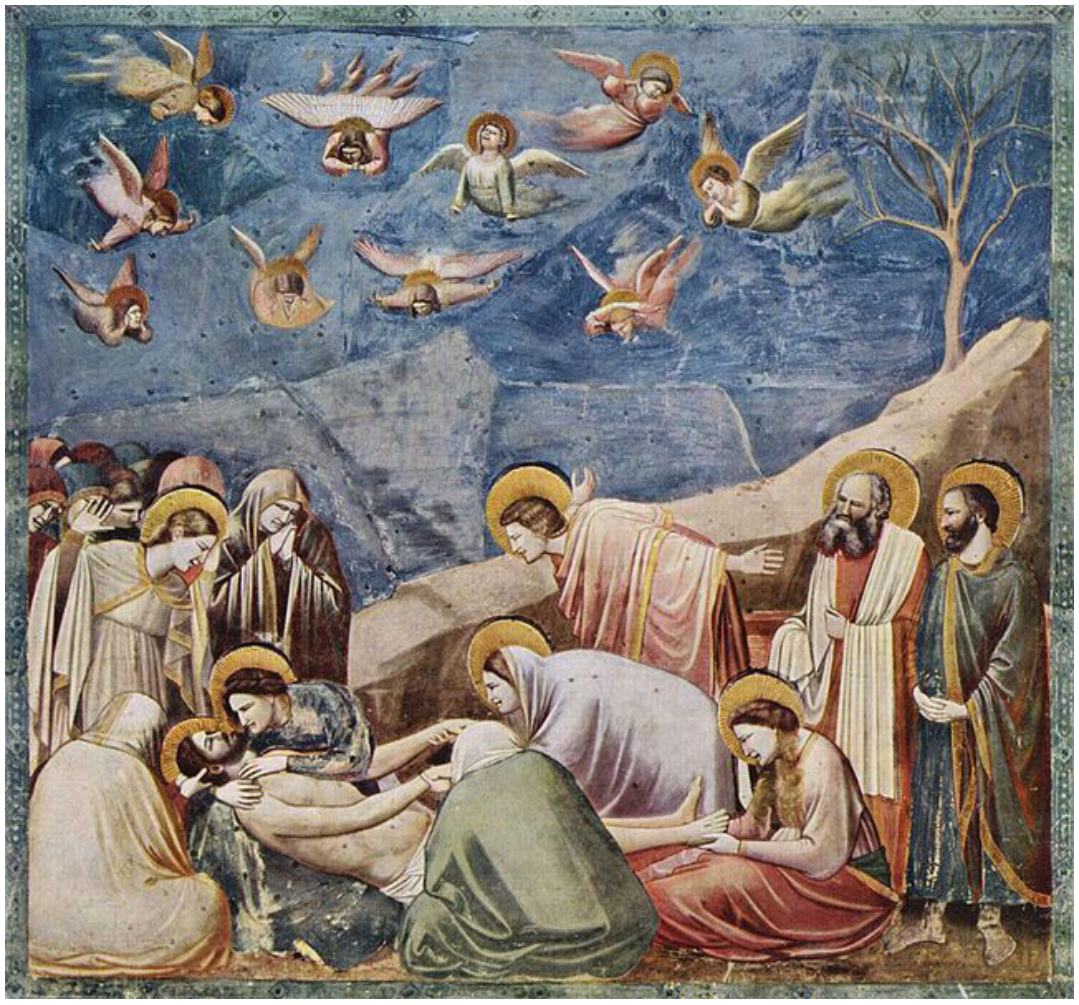

Figura 12 - Giotto da Bordone: Lamento pelo Cristo Morto, cca. 1305. Disponível em: https://pt.wikipedia. org/wiki/Ficheiro:Giotto_di_Bondone_oog.jpg

Todas essas técnicas de miscigenação de dimensões físicas e de técnicas de processamento conduziram a uma apropriação dos espaços não sagrados pelo espaço do templo cristão e consagraram uma forma de se relacionar com o mundo, que é distintiva da teleologia e do conceito neo-hegeliano, mas também cristão, de progresso do material.

O enodamento das artes acompanha, quase sempre, uma apreensão dos constructos em direção à realidade extra-estética. É, pois, estritamente contrário ao princípio da própria representação. Quanto mais enodamento um gênero acolhe [...] mais ele participa daquilo que nele é estranho e coisificado, ao invés de imitá-lo. A arte tornar-se-á virtualmente coisa entre coisas, tornar-se-á algo que não sabemos o que seja. Esse não-saber confere à arte uma expressão inevitável. ${ }^{19}$ (ADORNO, 1977, p. 450, tradução minha).
Aaproximação das linguagens seria, para Adorno, o motor dos aparentes paradoxos que Esclarecimento leva adiante: as linguagens são linguisticamente figuradas pela sobreposição de negações, evitando a falsa estabilidade das positividades. A esperança de uma reconciliação subsistiria no impronunciável nome de Deus - não é apenas o resíduo da dupla negação, da recusa da falsa esperança que Adorno e Horkheimer expõem na Dialética do Esclarecimento -, ela contém um sentido positivo em si. Em seu ensaio Música e Linguagem, Adorno diferencia a música daquilo a que chama linguagem significante (intencional), que é a linguagem instrumental da comunicação quotidiana:

Gegenüber der meinenden Sprache ist Musik eine von ganz anderem Typus. In ihm liegt ihr theologischer Aspekt. Was sie sagt, ist als Erscheinendes bestimmt zugleich und verborgen.

19 Do original: Die Verfransung der Kunstgattungen begleitet fast stets einen Griff der Gebilde nach der außerästhetischen Realität. Er gerade ist dem Prinzip von deren Abbildung strikt entgegengesetzt. Je mehr eine Gattung von dem in sich hineinläßt, l... desto mehr partizipiert sie am ihr Fremden, Dinghaften, anstatt es nachzuahmen. Sie wird virtuell zum Ding unter Dingen, zu jenem, von dem wir nicht wissen, was es ist. Solches Nicht-Wissen verleiht einem der Kunst Unausweichlichen Ausdruck. 
Ihre Idee ist die Gestalt des göttlichen Namens. Sie ist entmythologisiertes Gebet, befreit von der Magie des Einwirkens; der wie immer auch vergebliche menschliche Versuch, den Namen selber zu nennen, nicht Bedeutungen mitzuteilen. I... Sie verweist auf die wahre Sprache als auf eine, in der der Gehalt selber offenbar wird, aber um den Preis der Eindeutigkeit, die überging an die meinenden Sprachen. (ADORNO, p. 252253, fragmento sobre música e linguagem da Biblioteca Digital)

Para Adorno, o problema crucial com a linguagem é que ela pretende mediar o absoluto. Ela procuraria subsumir o particular no universal, e torná-lo conceitual, cognoscivel, e, assim, não absoluto. O absoluto é, por definição, "inacessivel" à mediação, ele existe por si, em independência absoluta. A linguagem intencional procura estabelecer uma relação com o absoluto, colocando-o em relação com as outras coisas todas. Esse procedimento só pode oferecer versões parciais do absoluto, limitadas pelo conceito. A verdadeira linguagem - como a linguagem da música - sacrifica a [possibilidade del clareza conceitual em prol pela imediatidade daquilo que evita a mediação. Em Adorno, linguagem e música são como uma luz unificadora, que desvelam a presença em sua inexaurivel totalidade, como um flash. Ao contrário de música e linguagem, não é articulada no tempo, é instantânea.

Die meinende Sprache möchte das Absolute vermittelt sagen, und es entgleitet ihr in jeder einzelnen Intention, läßt eine jede als endlich hinter sich zurück. Musik trifft es unmittelbar, aber im gleichen Augenblick verdunkelt es sich, so wie überstarkes Licht das Auge blendet, welches das ganz Sichtbare nicht mehr zu sehen vermag. (ADORNO, p. 254, fragmento sobre música e linguagem da Biblioteca Digital).

As resoluções do Concilio de Trento (15451563) deram seus frutos mais preciosos no século subsequente e praticamente criaram uma nova estética: o Barroco ${ }^{20}$. O Barroco é a expressão cabal da opção da Igreja de Roma por uma arte teatral, espetacular e humanística. Para responder às críticas dos reformistas luteranos ao Norte dos Alpes - de que os templos apelariam por demais aos sentidos, ao luxo e ao sensualismo -, as autoridades eclesiásticas que participaram do concilio não contemporizaram. Não cogitaram em reduzir o fausto e a arte nos templos, ao contrário, optaram, conscientemente, por ampliar o alcance e a dramaticidade do espetáculo, por acentuar a "fusão" de sacro e profano. Nas palavras de Émile Mâle (1932), "a Reforma, que queria destruir as imagens, multiplicou-as; ela fez surgir temas novos, deu aos antigos um significado e uma beleza novas; foi, enfim, sem dar-se conta, um dos estimulantes mais poderosos da arte católica." Besançon (2000) lembra que a arte profana não é apenas permitida, ela é "invocada" pela arte sacra. A terra também proclama, segundo o salmo, a glória do Eterno ${ }^{21}$.

A Contrarreforma, na arte, acentuou o teatralismo e dedicou-se a uma glorificação sensivel e quase sensual do suprassensivel. A exposição reiterada da pele nua dos mártires - um dos temas predominantes no século XVII - serviu à sublimação transcendente de tendências sensuais. Torna-se quase impossivel separar o "erótico" do "somático" na arte cristã barroca. E não apenas nas artes visuais: quando Claudio Monteverdi estreou suas Vésperas da Beta Virgem Maria (1610), em São Marcos (Veneza), os presentes escutaram uma colagem sem preconceitos de elementos do canto gregoriano tradicional, com longas entonações vocais no estilo do canto moçárabe dos muçulmanos. Não há registro de queixas por parte dos fieis.

No século XVIII, o rococó da Áustria e sul da Alemanha "acolheu" - não expulsou - a sensualidade, o lúdico e o efeminamento dos putti — os chamados "anjinhos barrocos" - em espaços marcados por luxo, luminosidade e desequilibrio (a simetria pitagórica esgotara suas possibilidades expressivas já no século XVII). E, em relação ao Neoclassicismo francês, qual a diferença entre a igreja da Madeleine, em Paris (Figura 13), e um templo romano a Júpiter? Apenas a deidade ali adorada. 


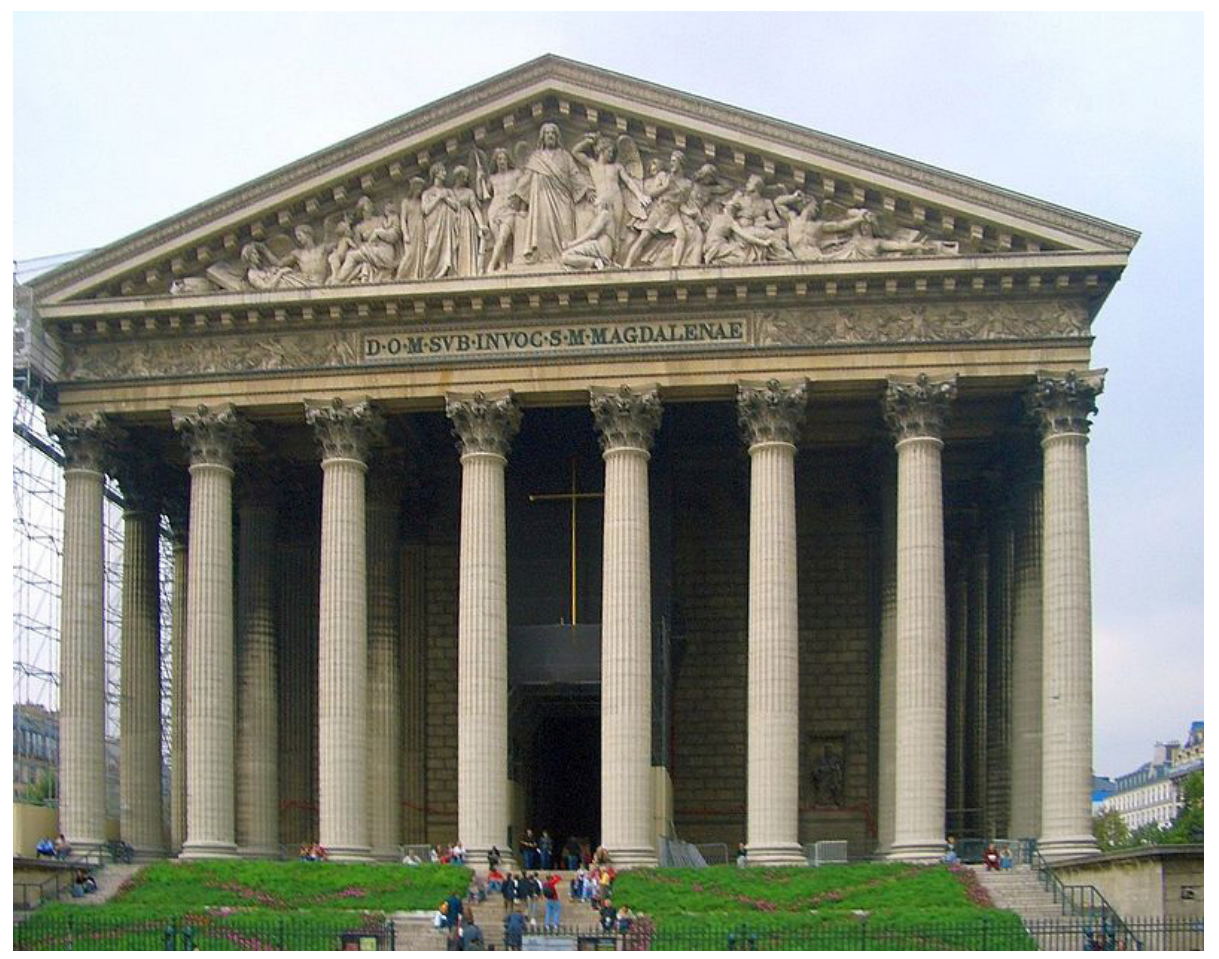

Figura 13 - Pierre-Alexandre Vignon: Igreja de Santa Maria Madalena, Paris, 1764-1828. Domínio público. Disponivel em: https://commons.wikimedia.org/w/index.php?curid=2442566

\section{Queermuseu - Propostas para uma leitura transversal}

Para terminar esta brevissima abordagem de um tema cuja discussão não deveria mais ser negligenciada na academia, algumas observações: é uma demanda ética acolher o sentimento de estranhamento frente às obras supracitadas (lembrando Wittgenstein: Ética e Estética são uma só22), mas é necessário fazer um exame de o quanto desse estranhamento foi estimulado por estratégias de desinformação. A tela de Fernando Baril, "Cruzando Jesus Cristo com Deusa Shiva", apenas atualiza o discurso de miscigenação de linguagens de que os artistas paleocristãos dos séculos II a $\vee$ foram os precursores. Os muitos braços do Cristo-Shiva são emanações análogas aos sefirot da tradição da cabala - coroa, sabedoria, entendimento, misericórdia, julgamento, beleza, vitória, esplendor, fundamento e reino -, os galhos que brotam das mãos do crucificado autorizam a fazer essa analogia com a árvore da vida (Figura 14).

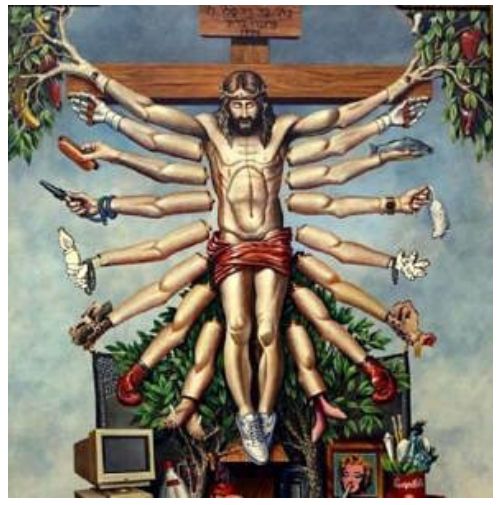

Figura 14 - Fernando Baril: Cruzando Jesus Cristo com Deusa Shiva. 1996. Título. Disponível em: https:// revistahibrida.com.br/revista/edicao-2/segunda-chance-para-queermuseu/cruzando-jesus-cristo-com-o-deus-shiva-obra-de-fernando-baril/

22 Citado em: Ethik und Ästhetik sind Eins. Die Philosophie Wittgensteins im Kontext ethischer und ästhetischer Fragestellungen. Disponivel em: http://www.uni-bielefeld.de/zll/abteilungen/hdle/materialien/Lehrkonzepte/Darstellung_des_Lehrprojekts_FLL_Markewitz_final.pdf acessado em 19/março/2019 
Os icones da cultura pop (Marilyn Monroe, lata de Campbell's, cachorro-quente etc) são parte constitutiva do caráter omnibus (universal) do Evangelho: a própria encarnação se explica pela necessidade de falar aos homens em uma linguagem que a todos seja visivel e acessivel. Nesse sentido, o Et verbum, de Antônio Obá (Figura 15), é uma pertinente releitura dos princípios da "dissemelhança" do Pseudo-Dionísio Areopagita.

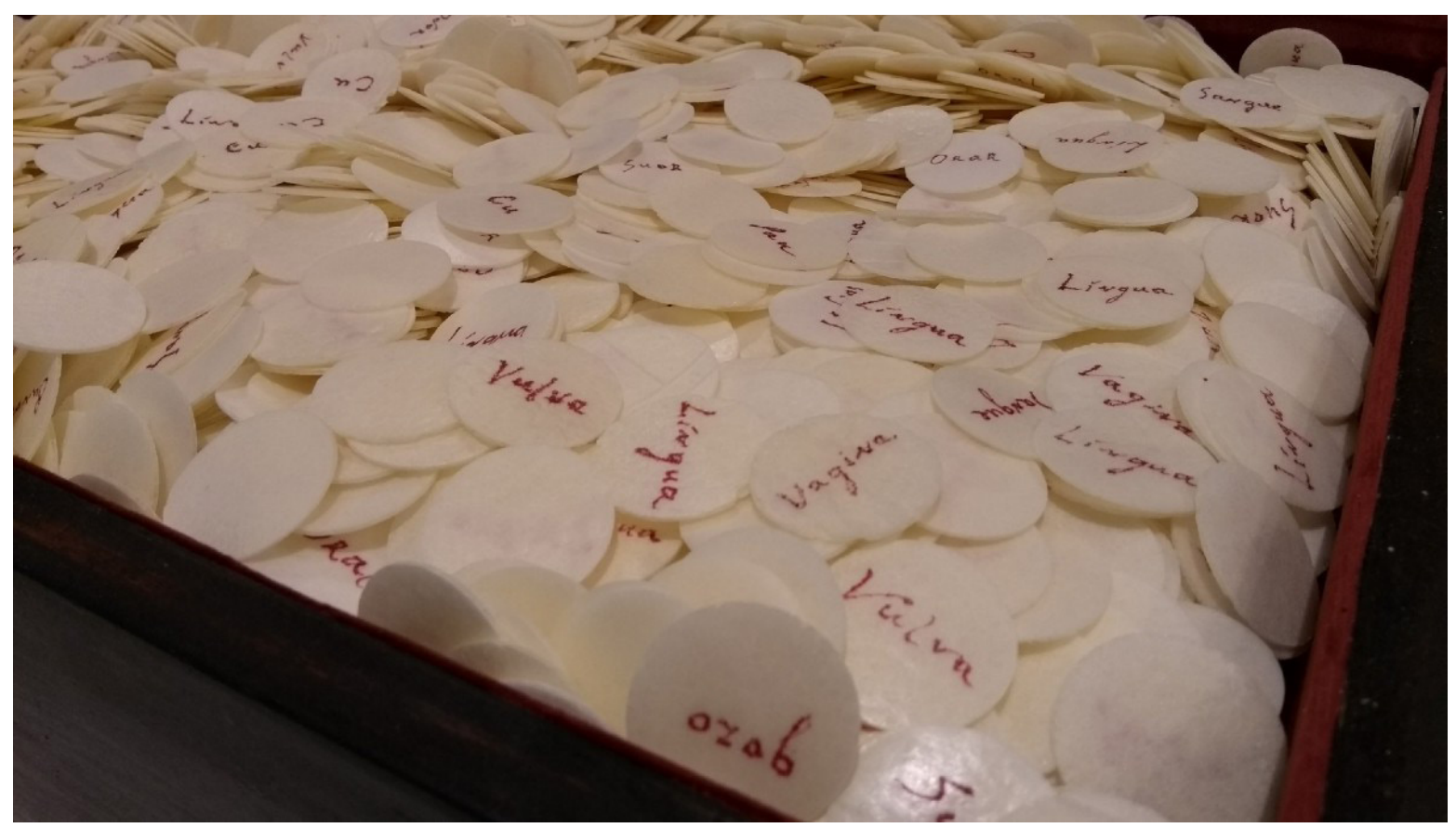

Figura 15 - Antônio Obá: Et verbum, 2011. Disponivel em: http://www.ipla.com.br/conteudos/artigos/o-que-quer-queer-dizer/

Ao superar o conceito de representação "semelhante", Obá explicita o que a todos deveria ser evidente: a relação entre eucaristia e antropofagia ${ }^{23}$. Não é possivel ingerir a carne de Deus sem que também se canibalize cada um de seus membros, mas essa percepção pode ser incômoda. Gaudêncio Fidelis, no catálogo da exposição, qualifica a obra de Obá apropriadamente como livro-objeto: o verbo se fez carne, habitou entre os homens, e sua história foi contada em um livro, 0 Evangelho. Ao abrir-se o livro-obra Et verbum, cujo título alude à encarnação do logos, expõem-se as dimensões da manifestação do Deus infinito em um homem mortal, sem negligenciar a menção às partes do seu corpo. É de se lamentar que uma parcela do público tenha sido levada a pensar que, ali, se tratasse de uma blasfêmia: o contrário, é mais crivel. Uma palavra sobre a necessidade do emprego de formas expressivas não ortodoxas como no Et verbum ...: quando surgiu, a arte cristã injetou um sopro de vida na arte clássica, que já dava sinais de esgotamento e repetição. A nova temática do Evangelho, com o anúncio de um mundo ilimitado do Bem e da Verdade, salvou a arte do Ocidente da esclerose hierática, em que se encontravam os objetos de culto das religiões greco-romanos. Para que aquele novo vigor se mantivesse, foi preciso, constantemente, recuperar a força comunicativa e provocativa do objeto artistico, e a Igreja entendeu com clareza que isso não poderia ser feito com a ritualização das práticas representativas. Como formulou Adorno (2003), "o papel da arte é introduzir o caos na ordem". Visto dessa perspectiva, o Et Verbum... de Obá está muito mais próximo dos iconoclastas bizantinos - em sua visão crítica à crueza da representação

23 A palavra tupi abaporu, inscrita em uma das partículas, dá a pista: significa antropofagia, ou, para ser mais exato, devoração de carne humana. 
do Cristo encarnado - que dos desinformados moralistas do Movimento Brasil Livre.

\section{Considerações finais}

Finalmente, parte do público parece não ter se dado conta de uma coisa: o verbo encarnado é indestrutivel! Recear pela integridade

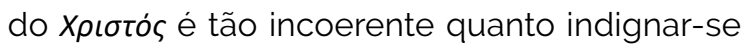
com a encarnação, por essa ter levado o verbo a consubstanciar-se em matéria. O que é preciso recear, sim, é pela corrupção do logos como discurso humano: pelo perigo de pessoas bem intencionadas - as quais são, ao fim e ao cabo, parte da ecclesia - poderem ser levadas a odiar e agredir artistas e obras de arte - não sacra, mas cristã -, investigadoras da interação de realidade material e narrativa do Evangelho. É preciso ter consciência de que o Cristianismo está imbricado, de forma inseparável, na história do Ocidente. Não é possivel esperar outra coisa senão o recurso aos seus ícones e textos no processo de tomada de consciência de quem somos - esse processo é levado adiante, entre outros, pelos artistas. Esse recurso será, muitas vezes, visceral, violento, com a violência de quem precisa superar-se para livrar-se do conceitual e constituir-se no mundo das relações humanas. Esse diálogo - pautado por explosões cíclicas - é constitutivo da história de formação da sociedade ocidental, em seu processo de autoconhecimento.

\section{Referências}

ADORNO, T. Die Kunst und die Künste in Kulturkritik und Gesellschaft I/II. Gesammelte Schriften (Hsg. Rolf Tiedemann). Frankfurt: Suhrkamp, 1977.

ADORNO, T. Musikalische Schriften I-III. Fragmento sobre música e linguagem. Volume 97 da Biblioteca Digital: Theodor W. Adorno: Gesammelte Schriften, S. 13010 (vgl. GS 16, S. 252-253)].

ADORNO, T. Minima Moralia. Reflexionen aus dem beschädigten Leben: In nuce. Digitale Bibliothek Band 97: Theodor W. Adorno: Gesammelte Schriften, S. 2092 (vgl. GS 4, S. 253)], 2003.

ADORNO, T. Philosophie der neuen Musik. Frankfurt: Suhrkamp, 1997.

ALBERTO MAGNO, S. Tenebra luminosissima: Commento alla Teologia Mistica di Dionigi l'Areopagita. Palermo: Officina di Studi Medievali, 2007.
ARENDT, Hannah. Was ist Politik? München, Piper Verlag, 1993.

ASSUNTO, R. Die Theorie des Schönen im Mittelalter. Köln, DuMont, 1963. In: BALTHASAR, Urs von. Le Christ est-il beau? Disponivel em : http://Www.assomption.org/fr/mediatheque/ revue-itineraires-augustiniens/itineraires-augustiniens-ndeg31-la-beaute/ii-augustin-maitre-spirituel/ le-christ-est-il-beau-par-urs-von-balthasar. Acesso em: 11/11/2020.

BAUMAN, Z. O mal-estar da pós-modernidade. Rio de Janeiro: Jorge Zahar Ed., 1998.

BAUMGARTEN, A. G. Ästhetik - Übersetzt, mit einer Einführung, Anmerkungen und Registern herausgegeben von Dagmar Mirbach. Hamburg: Felix Meiner Verlag, 2007.

BENJAMIN, W. Über den Begriff der Geschichte. Frankfurt : Suhrkamp, 2002.

BESANÇON, Alain. L'art et le christianisme em Christianisme, héritages et destins. Paris, Le livre de poche, $\mathrm{n}$. 4318, 2002. Disponivel em: https://academiesciencesmoralesetpolitiques.fr/wpcontent/uploads/2018/05/ art_christianisme.pdf. Acesso em: 11/11/2020.

BÍBLIA DE JERUSALÉM. São Paulo: Paulus, 1995.

BROWN, P. The Book of Kells. New York: Knopf, 1980.

ECO, Umberto. História da beleza. Rio de Janeiro. Record, 2004.

FIGUEIREDO, E. Desfazendo o gênero: a teoria queer de Judith Butler. Criação \& Crítica, n. 20, 2018. Disponivel em: http://www.revistas.usp.br/criacaoecritica/ article/download/138143/139436/290774 Acesso em: 11/11/2020.

GRASSI, E. Arte como antiarte. São Paulo: Duas cidades, 1975

GRASSI, E. Poder da imagem, impotência da palavra racional. São Paulo: Duas cidades, 1978.

JEDIN, H. Historia del Concilio de Trento. Pamplona: Univ. de Navarra, 1972.

LESSING, G. E. Laocoonte ou sobre as fronteiras da pintura e da poesia: com esclarecimentos ocasionais sobre diferentes pontos da história da arte antiga. Introdução, tradução e notas Márcio Seligmann-Silva. São Paulo: Iluminuras, 1998.

LICHTENSTEIN, J. A pintura, Vol. 2: A teologia da imagem e o estatuto da pintura. São Paulo: Editora 34, 2004.

MÂLE, E. L'Art religieux après le Concile de Trente, étude sur l'iconographie de la fin du XVIe, du XVII e et du XVIII siècles en Italie, en France, en Espagne et en Flandre, 1932. Persee. Disponivel em http://www.persee.fr/doc/ rscir_0035-2217_1933_num_13_1_1579_t1_0130_0000_2. Acesso em: 01/12/2017.

METZSCH, F. A. Bild und Botschaft. Regensburg: Schnell und Steiner, 2004.

NIETZSCHE, F. Die Geburt der Tragödie. In: NIETZSCHE, F. Nietzsches Werke. Salzburg: Bergland, 1952. 
OSTER, C. Die Farben höfischer Körper: Farbattribuierung und höfische Identität in mittelhochdeutschen Artus und Tristanromanen. Berlin: Walter de Gruyter, 2014.

PANOFSKY, E. Arquitetura gótica e Escolástica. São Paulo: Marins Fontes, 2001.

PANOFSKY, E. Significado nas artes visuais. São Paulo: Editora Perspectiva, 2002.

PANOFSKY, E. Studien zur Ikonologie. Köln: DuMont, 1980.

PLAZAOLA, J. Historia y sentido del arte Cristiano. Madrid: BAC, 1996.

SPENCER, M. D. Understanding Four Quartets as a Religious Poem. Lewinston: Edwin Mellen Press, 2008.

WIND, E. Misteri pagani nel Rinascimento. Milano: Adelphi Edizioni, 1999.

Endereço para correspondência

Ronel Alberti da Rosa

Avenida Ipiranga, 6681

Prédio 9 - térreo, sala 119

Porto Alegre/RS - Brasil - CEP 90619-900

Os textos deste artigo foram revisados pela Zeppelini Publishers e submetidos para validação do(s) autor(es) antes da publicação. 